\title{
Larvicidal, antimicrobial and brine shrimp activities of extracts from Cissampelos mucronata and Tephrosia villosa from coast region, Tanzania
}

\author{
Ramadhani S O Nondo ${ }^{*}$, Zakaria H Mbwambo², Abdul W Kidukuli, Ester M Innocent', Matobola J Mihale ${ }^{3}$,
} Paul Erasto ${ }^{2}$ and Mainen J Moshi ${ }^{1}$

\begin{abstract}
Background: The leaves and roots of Cissampelos mucronata A. Rich (Menispermaceae) are widely used in the tropics and subtropics to manage various ailments such as gastro-intestinal complaints, menstrual problems, venereal diseases and malaria. In the Coast region, Tanzania, roots are used to treat wounds due to extraction of jigger. Leaves of Tephrosia villosa (L) Pers (Leguminosae) are reported to be used in the treatment of diabetes mellitus in India. In this study, extracts from the roots and aerial parts of C. mucronata and extracts from leaves, fruits, twigs and roots of T. villosa were evaluated for larvicidal activity, brine shrimps toxicity and antimicrobial activity.

Methods: Powdered materials from C. mucronata were extracted sequentially by dichloromethane followed by ethanol while materials from T.villosa were extracted by ethanol only. The extracts obtained were evaluated for larvicidal activity using Culex quinquefasciatus Say larvae, cytotoxicity using brine shrimp larvae and antimicrobial activity using bacteria and fungi.

Results: Extracts from aerial parts of C. Mucronata exhibited antibacterial activity against Staphylococcus aureus, Escherichia coli, Pseudomonas aeruginosa, Salmonella typhi, Vibrio cholera, Bacillus anthracis, Streptococcus faecalis and antifungal activity against Candida albicans and Cryptococcus neoformans. They exhibited very low toxicity to brine shrimps and had no larvicidal activity. The root extracts exhibited good larvicidal activity but weak antimicrobial activity. The root dichloromethane extracts from C. mucronata was found to be more toxic with an $L C_{50}$ value of $59.608 \mathrm{\mu g} / \mathrm{mL}$ while ethanolic extracts from root were not toxic with $\mathrm{LC}_{50}>100 \mu \mathrm{g} / \mathrm{mL}$ ). Ethanol extracts from fruits and roots of $T$. villosa were found to be very toxic with $L C_{50}$ values of $9.690 \mu \mathrm{g} / \mathrm{mL}$ and $4.511 \mu \mathrm{g} / \mathrm{mL}$, respectively, while, ethanol extracts from leaves and twigs of $T$. villosa were found to be non toxic $\left(L_{50}>100 \mu \mathrm{g} / \mathrm{mL}\right)$.

Conclusion: These results support the use of C. mucronata in traditional medicine for treatment of wounds. Extracts of C. mucronata have potential to yield active antimicrobial and larvicidal compounds. The high brine shrimp toxicity of $T$. villosa corroborates with literature reports that the plant is toxic to both livestock and fish. The results further suggest that $T$. villosa extracts have potential to yield larvicidal and possibly cytotoxic compounds. Further studies to investigate the bioactive compounds responsible for the observed biological effects are suggested.
\end{abstract}

\footnotetext{
* Correspondence: nondo75@yahoo.com

${ }^{1}$ Department of Biological and Pre-Clinical Studies, Institute of Traditional Medicine, Muhimbili University of Health and Allied Sciences (MUHAS),

P.O. Box 65001, Dar es Salaam, Tanzania

Full list of author information is available at the end of the article
} 


\section{Background}

Cissampelos mucronata A. Rich (Menispermaceae) or kishiki cha buga (Swahili) is a dioecious liana found in tropical and subtropical areas of Africa, America and Asia [1-3]. It is widely used as traditional herbal medicine [2]. In the Coast region, Tanzania, the powdered roots of C. mucronata are mixed with coconut oil for treatment of fresh wounds after extraction of jigger (Tunga penetrans) while in other parts of Tanzania, C. mucronata is used for treatment of indigestion, fever due to malaria and wounds $[4,5]$. In South Africa, the root decoction is used for the treatment of schistosomiasis while in India roots are used as antisnake venom [6,7]. Pharmacologically root extracts of $C$. mucronata are reported to be active against chloroquine - sensitive and chloroquine resistant $P$. falciparum strains, and active against Trypanosoma cruzi and Trypanosoma rhodensiense $[5,8]$. Other pharmacological properties of root extracts include sedative effect and antimicrobial activity [9,10]. Extracts from leaves are reported to have antibacterial, anti-ulcer and hypoglycaemic activities as well as uterine relaxant properties [11-13].

Tephrosia villosa L. Pers (Fabaceae) is an annual or perennial bushy herb which is commonly found on sandy soil. Despite being reported to be toxic to livestock and fish [14], aqueous extract of T. villosa leaves is used as herbal remedy in the treatment of diabetes mellitus in India [15,16]. In Africa, the herb is used as green manure to improve the soil [14].

The aim of this study was to evaluate the ethanolic and dichloromethane extracts from roots and aerial parts of C. mucronata as well as ethanolic extracts from leaves, fruits, twigs and roots of T. villosa for larvicidal and antimicrobial activity. The brine shrimp toxicity test was used to evaluate the extracts for toxicity and potential cytotoxic activity.

\section{Methods}

\section{Materials}

Dichloromethane was purchased from UNILAB (UNILAB $^{\circledR}$, Nairobi, Kenya), ethanol (absolute) was bought from Fluka Chemie GmbH (Sigma-Aldrich ${ }^{\circledR}$, Zwijndrecht, Netherlands) whereas Dimethyl sulfoxide (DMSO) was purchased from Sigma ${ }^{\circledR}$ (Poole, Dorset, UK). Saboraud's broth was bought from HIMEDIA ${ }^{\circledR}$ (Himedia Laboratories Pvt Ltd, Mumbai, INDIA) while Nutrient broth was purchased from Tulip Diagnostic (P) Ltd (Microxpress ${ }^{\mathrm{TM}}$, Goa, INDIA). Staphylococcus aureus (NCTC 25923), Escherichia coli (ATCC 25922), Pseudomonas aeruginosa (ATCC 29953), Salmonella typhi (NCTC 8385), Vibrio cholera (clinical isolate), Bacillus anthracis (NCTC10073), Streptococcus faecalis (clinical isolate), Candida albicans (ATCC 90028) and Cryptococcus neoformans (clinical isolate) were obtained from the Department of Microbiolgy, Muhimbili University of Health and Allied Sciences (MUHAS). Iodonitrotetrazolium chloride was bought from SIGMA ${ }^{\circledR}$ (Sigma- Aldrich ${ }^{\circledR}$, St Louis, USA). The Brine Shrimps eggs were purchased from Aquaculture innovations (Grahamstown 6140, South Africa) and sea salt was prepared locally by evaporating water collected from the Indian Ocean, along the Dar es Salaam Coast. Mosquito larva, Culex quinquefasciatus Say., were obtained and reared at the Institute of Traditional Medicines - MUHAS.

\section{Collection and Preparation of Plant Materials}

The roots and aerial parts (twigs and leaves) of C. mucronata, voucher specimen no. 3960 were collected from Bagamoyo District, while roots, twigs, leaves and fruits of T. villosa, voucher specimen no. 3961 was collected from Kibaha District, Coast region, Tanzania. The plants were identified by Mr. Haji Selemani, a botanist from the Department of Botany, University of Dar es Salaam. The plant materials were dried under shade and then pulverized to get powders for extraction.

\section{Extraction process}

The plant powders from the roots and aerial parts of C. mucronata were extracted sequentially by maceration using dichloromethane and ethanol whereas fruits, leaves, twigs, and roots of T. villosa were separately extracted using ethanol only (100\%). The extracts were dried under vacuo using rotary evaporator and stored at $-20^{\circ} \mathrm{C}$ until the time for testing.

\section{Testing for larvicidal activity}

The larvicidal test was performed according to World Health Organisation (WHO) protocol with minor modification [17]. Briefly, stock solutions (50 mg/mL) of each plant extract were prepared by first dissolving them in DMSO. The stock solutions were diluted with distilled water to make $100 \mathrm{~mL}$ each, of 500, 250, 100 and $50 \mu \mathrm{g} / \mathrm{mL}$ solutions of each plant extract. Ten late third instar laboratory reared C. quinquefasciatus mosquito larvae were then introduced in the test solution and mortality was observed after $24 \mathrm{~h}, 48 \mathrm{~h}$ and $72 \mathrm{~h}$. Negative control tests contained mosquito larvae, DMSO $(0.5 \%)$ and water only. All tests were carried out in duplicate under controlled temperature $\left(25 \pm 2^{\circ} \mathrm{C}\right)$ and relative humidity of $75-85 \%$. The number of dead larvae was recorded after $24 \mathrm{~h}, 48 \mathrm{~h}$, and $72 \mathrm{~h}$, and the mean percentage mortalities calculated for each concentration. The mean results of the percentage mortality were plotted against the logarithms of concentrations using the Fig P computer program (Biosoft Inc, USA). The concentrations killing fifty percent of the larvae $\left(\mathrm{LC}_{50}\right)$ 
were calculated from the regression equations obtained from the graphs.

\section{Testing for antimicrobial activity}

Minimum inhibitory concentrations (MICs) were determined by microdilution method [18] using 96-well microtitre plates. The plates were first preloaded with $50 \mu \mathrm{L}$ of the broth media in each well followed by an addition of $50 \mu \mathrm{L}$ of the extract $(100 \mathrm{mg} / \mathrm{mL})$ into the first wells of each row tested to make a total volume of $100 \mu \mathrm{l}$ in the first wells. After thorough mixing $50 \mu \mathrm{l}$ were drawn from each of the first row wells and put into the next row wells. The process was repeated down the columns to the last wells at the bottom where $50 \mu \mathrm{L}$ was discarded. Thereafter, $50 \mu \mathrm{L}$ of the bacterial suspension (0.5 Mac Farhland standard turbidity) was then added in each well to make the final volume of $100 \mu \mathrm{L}$ in each well. The rows containing Gentamicin sulphate (50 - $0.024 \mu \mathrm{g} / \mathrm{mL}$ ) was used as a standard positive drug, DMSO as negative control while the rows with broth and bacteria only was used to monitor bacterial growth. The plates were then incubated at $37^{\circ} \mathrm{C}$ for $24 \mathrm{~h}$. For each extract, MICs were determined by adding $40 \mu$ Lof $0.02 \% p$-iodonitrotetrazolium (INT) chloride dye in each well followed by incubation for $1 \mathrm{~h}$ at $37^{\circ} \mathrm{C}$. Bacterial growth was indicated by a change in pink colour. The lowest concentration which showed no bacterial growth was considered as MIC.

\section{Brine shrimps lethality test}

Brine shrimps lethality test (BST) was used to predict the presence of bioactive compounds in the extract [19]. Briefly, stock solutions $(40 \mathrm{mg} / \mathrm{mL})$ of all extracts were prepared by dissolving them in DMSO. Different levels of concentrations $(240,120,80,40,24$ and $8 \mu \mathrm{g} / \mathrm{mL}$ ) were prepared by drawing different volumes from the stock solutions and then added into vials, each containing ten brine shrimps larvae. The volume was then adjusted to $5 \mathrm{~mL}$ with artificial sea water prepared by dissolving $3.8 \mathrm{~g}$ of sea salt in $1 \mathrm{~L}$ of distilled water. Each level of concentration was tested in duplicate. The negative control contained brine shrimp, artificial sea water and DMSO $(0.6 \%)$ only. The vials were incubated under light for $24 \mathrm{~h}$. The dead larvae were counted and mean was subjected to analysis using Fig P computer program (Biosoft Inc, USA).

\section{Data analysis}

The mean results of the percentage mortality were plotted against the logarithms of concentrations using the Fig P computer program. Regression equations obtained from the graphs were used to obtain $\mathrm{LC}_{16}$, $\mathrm{LC}_{50}, \mathrm{LC}_{84}$ and the $95 \% \mathrm{CI}$ values [20]. An $\mathrm{LC}_{50}$ value greater than $100 \mu \mathrm{g} / \mathrm{mL}$ is considered to represent an inactive compound or extract.

\section{Results \\ Larvicidal and Brine shrimp Activity}

Larvicidal activity of ethanol and dichloromethane extracts from both roots and aerial parts of C. mucronata were evaluated after incubating mosquito larvae with different concentrations of extracts for $72 \mathrm{~h}$. After 24. h of larvae exposure, ethanolic and dichloromethane root extracts from C. mucronata, CMRE and CMRD, respectively were found to have larvicidal activity whereas ethanolic and dichloromethane extracts from aerials parts of C. mucronata, CMAD and CMAE, respectively were found to have no activity against C. quinquefasciatus larvae (Table 1). However, among the active extracts, the dichloromethane root extract, CMRD exhibited high larvicidal activity with an $\mathrm{LC}_{50}$ value of $126.11 \mu \mathrm{g} / \mathrm{mL}$ than ethanolic root extracts, CMRE which had an $\mathrm{LC}_{50}$ value of $219.99 \mu \mathrm{g} / \mathrm{mL}$. Generally the larvicidal activity increased slightly with the increase in the time of exposure except for CMAD which was found to be inactive even after $72 \mathrm{~h}$ of larvae exposure to different concentrations of this extract. Among the extracts from C. mucronata, the highest larvicidal activity was observed with CMRD extract which had an $\mathrm{LC}_{50}$ value of $117.09 \mu \mathrm{g} / \mathrm{mL}$ ) after $72 \mathrm{~h}$ of exposure.

All extracts from $T$. villosa showed larvicidal activity (Table 1) against mosquito larvae after $24 \mathrm{~h}$ of incubation with $\mathrm{LC}_{50}$ values ranging from $65 \mu \mathrm{g} / \mathrm{mL}$ to $220 \mu \mathrm{g} / \mathrm{mL}$. However, after this time of exposure, ethanolic fruit extract from $T$. villosa, TVFE, exhibited the best larvicidal activity with $\mathrm{LC}_{50}$ value of $65.75 \mu \mathrm{g} / \mathrm{mL}$ as compared to other extracts from $T$. villosa. Larvicidal activity was increased with the time of exposure. At day three, TVFE was found to be more active against $C$. quinquefasciatus larvae with an $\mathrm{LC}_{50}$ value of $53.25 \mu \mathrm{g} / \mathrm{mL}$ while the ethanolic leaf extract from $T$. villosa (TVLE), was found to be less active with an $\mathrm{LC}_{50}$ value of $161.61 \mu \mathrm{g} / \mathrm{mL}$.

Brine shrimps results as indicated in Table 2 show that all extracts from aerial parts and ethanolic root extract from C. mucronata were not toxic to brine shrimp larvae, giving $\mathrm{LC}_{50}$ values above $100 \mu \mathrm{g} / \mathrm{mL}$. The root dichloromethane extracts of C.mucronata was found to be the most toxic to brine shrimp $\left(\mathrm{LC}_{50}=59.608 \mu \mathrm{g} / \mathrm{mL}\right)$. Ethanolic extracts of the fruits (TVFE) and roots (TVRE) of T.villosa, were highly toxic to brine shrimp larvae with $\mathrm{LC}_{50}$ values below $10 \mu \mathrm{g} / \mathrm{mL}$. The ethanolic root extract of $T$. villosa was however the most toxic extract with an $\mathrm{LC}_{50}$ value of $4.5 \mu \mathrm{g} / \mathrm{mL}$. Ethanolic extracts from leaves (TVLE) and twigs (TVTE) were non toxic with $\mathrm{LC}_{50}$ values above $100 \mu \mathrm{g} / \mathrm{mL}$ (Table 2). 
Table 1 Larvicidal activity of extracts from C.mucronata and T. villosa

\begin{tabular}{|c|c|c|c|}
\hline \multirow[t]{3}{*}{ Plant extracts } & \multicolumn{3}{|c|}{ Larvicidal activity } \\
\hline & \multicolumn{3}{|c|}{$\mathrm{LC}_{50} \mu \mathrm{g} / \mathrm{ml}(95 \% \mathrm{Cl})$} \\
\hline & 24 h (Day 1) & 48 h (Day 2) & 72 h (Day 3) \\
\hline CMAE & a & $26891.0(5252.15-137681.92)$ & 7999.935 (3440.83 - 18599.8) \\
\hline CMRE & $219.99(180.91-267.51)$ & $217.12(205.77-229.60)$ & $207.12(196.00-219.01)$ \\
\hline CMAD & $a$ & $a$ & $a$ \\
\hline CMRD & $126.11(104.14-152.72)$ & $122.91(101.33-149.09)$ & $117.09(95.59-143.44)$ \\
\hline TVFE & $65.75(51.58-77.78)$ & $54.465(48.022-59.713)$ & $53.25(45.67-62.09)$ \\
\hline$\overline{T V L E}$ & $213.59(201.05-227.59)$ & $169.75(155.34-185.03)$ & $161.61(147.99-176.07)$ \\
\hline TVTE & $126.16(105.70-145.21)$ & $74.724(66.798-82.347)$ & $71.171(63.739-78.072)$ \\
\hline TVRE & $218.47(198.88-238.97)$ & $107.61(89.26-124.36)$ & $71.50(54.11-86.15)$ \\
\hline
\end{tabular}

\section{Antimicrobial Activity}

All the extracts from C. mucronata and T. villosa exhibited activity against at least one organism tested (Table 3). C. mucronata aerial parts and root extracts were found to be active against both bacteria and fungi. The aerial parts dichloromethane and ethanolic extracts exhibited the highest activity. The ethanolic aerial part extracts of $C$. mucronata was most active against $V$. cholera with MIC value of $0.391 \mathrm{mg} / \mathrm{mL}$ while the dichloromethane of the same was more active against S. typhi, B. anthracis and C. neoformans with MIC values of $0.781 \mathrm{mg} / \mathrm{mL}$, $0.195 \mathrm{mg} / \mathrm{mL}$ and $0.195 \mathrm{mg} / \mathrm{mL}$, respectively. The ethanolic root extract from $C$. mucronata exhibited low activity against B. anthracis, V. cholera, S. faecalis, C. albicans and C. neoformans with $\mathrm{MIC}$ values ranging between $1.563 \mathrm{mg} / \mathrm{mL}$ and $3.125 \mathrm{mg} / \mathrm{mL}$ (Table 3).

Among the T.villosa extracts the best activity was exhibited by the fruit extracts against C.neoformans with MIC value of $0.195 \mathrm{mg} / \mathrm{mL}$, leaf extract against $E$. coli with MIC value of $0.781 \mathrm{mg} / \mathrm{mL}$ and roots extract against B.anthracis with MIC value of $0.195 \mathrm{mg} / \mathrm{mL}$. Most of the organisms tested were less sensitive to the ethanolic twig extract (TVTE) except $C$. neoformans $(\mathrm{MIC}=1.563 \mathrm{mg} / \mathrm{mL})$ and S. typhi $(\mathrm{MIC}=3.125 \mathrm{mg} / \mathrm{mL})$.

\section{Discussion}

Leaves and roots of $C$. mucronata are used by some communities to treat venereal diseases, wounds and gastrointestinal complaints such as diarrhoea and dysentery $[1,8]$. T. villosa is reported to be toxic to animals and fish; however, in India it is used in the treatment diabetes mellitus [16]. There is no larvicidal activity is reported before for C. mucronata and T. villosa. Therefore, in this study, larvicidal, antimicrobial and brine shrimp activities were evaluated to determine the medicinal value and safety of these plant species.

The larvicidal activity assay was used to predict the presence of bioactive compounds that are able to kill mosquito larvae (C. quinquefasciatus larvae) or disrupt their development towards the adult form which is

Table 2 Brine shrimp activity of extracts from C.mucronata and T. villosa

\begin{tabular}{lllll}
\hline Plant extracts & Regression equation & LC $_{\mathbf{5 0}}(\boldsymbol{\mu} \mathbf{g} / \mathbf{m l})$ & $\mathbf{9 5 \%}$ Confidence interval $(\mathbf{C l})$ & Regression coefficient $(\mathbf{r})$ \\
\hline CMAE & $Y=65.1169 \log x-86.7002$ & 125.691 & $90.1016-175.339$ & 0.926045 \\
\hline CMRE & $Y=114.1741 \log x-196.0862$ & 143.008 & $115.608-176.901$ & 0.918404 \\
\hline CMAD & $Y=90.1643 \log x-135.5126$ & 114.155 & $113.329-145.205$ & 0.935504 \\
\hline CMRD & $Y=85.4278 \log x-101.6604$ & 59.608 & $46.244-76.835$ & 0.975568 \\
\hline TVFE & $Y=68.4308 \log x-17.4949$ & 9.690 & $7.058-13.304$ & 0.968423 \\
\hline TVLE & $Y=127.7823 \log x-221.9319$ & 134.304 & $111.087-162.373$ & 0.899348 \\
\hline TVTE & $Y=68.0408 \log x-111.7285$ & 238.196 & $166.687-340.382$ & 0.969139 \\
\hline TVRE & $Y=95.0056 \log x-12.1626$ & 4.511 & $3.589-5.670$ & 0.999793 \\
\hline Cyclophosphamide & $Y=69.9680 \log x-34.9360$ & 16.365 & $12.006-22.305$ & 0.994929
\end{tabular}

CMAE = Cissampelos mucronata aerial parts extract (100\% ethanol), CMRE = Cissampelos mucronata root extract (100\% ethanol), CMAD = Cissampelos mucronata aerial parts extract (dichloromethane), CMRD = Cissampelos mucronata root extract (dichloromethane), TVFE = Tephrosia villosa fruits extract (100\% ethanol), TVLE $=$ Tephrosia villosa leaves extract $(100 \%$ ethanol), TVTE $=$ Tephrosia villosa twigs extract $(100 \%$ ethanol), TVRE $=$ Tephrosia villosa root extract $(100 \%$ ethanol). 
Table 3 Antimicrobial activity of extracts from C.mucronata and T. villosa

\begin{tabular}{llllllllll}
\hline Plant extracts & \multicolumn{7}{c}{ minimum inhibitory concentration, MIC (mg/mL) } \\
\hline & S. aureus & E. coli & P. aeruginosa & S. typhi & V. cholera & B. anthracis & S. faecalis & C. albicans & C. neoformans \\
\hline CMAE & 3.125 & 6.250 & 6.250 & 3.125 & 0.391 & 3.125 & 12.5 & 1.563 & 1.563 \\
\hline CMRE & 12.50 & 6.250 & 12.50 & 6.250 & 3.125 & 3.125 & 3.125 & 3.125 & 1.563 \\
\hline CMAD & 6.250 & 6.250 & 12.50 & 0.781 & 3.125 & 0.195 & 6.25 & 3.125 & 0.195 \\
\hline CMRD & $>25.0$ & $>25.0$ & $>25.0$ & $>25.0$ & $>25.0$ & $>25.0$ & $>25.0$ & $>25.0$ & $>25.0$ \\
\hline TVFE & 6.25 & 12.50 & 12.5 & 3.125 & 3.125 & 1.56 & 12.5 & 12.5 & 0.195 \\
\hline TVLE & 12.50 & 0.781 & 1.563 & 3.125 & 12.50 & 1.563 & 12.50 & 1.563 & 6.25 \\
\hline TVTE & 6.250 & 12.50 & 12.50 & 3.125 & 6.250 & 12.50 & 12.50 & 12.5 & 1.563 \\
\hline TVRE & 1.563 & 12.50 & 12.50 & 3.125 & 6.250 & 0.195 & 3.125 & 12.50 & 6.25 \\
\hline $\begin{array}{l}\text { Standard antibacterial drug } \\
\text { (Gentamicin) }\end{array}$ & 0.000781 & 0.003125 & 0.001563 & 0.00625 & 0.001563 & 0.003125 & 0.0000244 & NA & NA \\
\hline
\end{tabular}

CMAE = Cissampelos mucronata aerial parts extract (100\% ethanol), CMRE = Cissampelos mucronata root extract (100\% ethanol), CMAD = Cissampelos mucronata aerial parts extract (dichloromethane), CMRD = Cissampelos mucronata root extract (dichloromethane), TVFE = Tephrosia villosa fruits extract (100\% ethanol), TVLE = Tephrosia villosa leaves extract (100\% ethanol), TVTE = Tephrosia villosa twigs extract (100\% ethanol), TVRE = Tephrosia villosa root extract (100\% ethanol), NA = applicable.

responsible for disease transmission [17]. Similarly, the brine shrimp lethality test is normally used to predict presence of toxic bioactive compounds but also possible presence of compounds with potential anticancer activity [21]. In this regard, ethanol and dichloromethane root extracts from C. mucronata exhibited high larvicidal activity, with the highest activity observed with dichloromethane extract which had the $\mathrm{LC}_{50}$ value of $117.09 \mu \mathrm{g} / \mathrm{mL}$. C. mucronata aerial part extracts did not exhibit any larvicidal activity. The extract is generally regarded as non-toxic if its $\mathrm{LC}_{50}$ is greater than $100 \mu \mathrm{g} / \mathrm{mL}$ in the brine shrimp lethality assay [21]. In this case, ethanolic extract of the roots of $C$. mucronata had larvicidal activity but not toxic, while dichloromethane extract showed larvicidal activity but also observed to be toxic. The literature report that the root extract of $C$. mucronata is active against chloroquine-sensitive and chloroquine-resistant P. falciparum malaria parasites [5], which is transmitted by Anopheles mosquito. Mosquitoes are responsible for the spread of various vector born diseases including malaria which is found in more than 100 countries in the world [22]. Although there are several ways of preventing the mosquito borne-diseases, one of the best option to prevent the spread of those diseases is to control mosquito vector by using larvicides. However, resistance and environment damage caused by synthetic agents have prompted for the search for environmental friendly and effective larvicides from plant sources [23]. In this study, results have shown that ethanol extract of the roots of C. mucronata may be useful as larvicidal agent.

Based on arguments by Aligiannis et al., 2001 [24], extracts from C. mucronata with promising antimicrobial activity were CMAE against $V$. cholera $(\mathrm{MIC}=$ $0.391 \mathrm{mg} / \mathrm{mL}$ ) and CMAD against B. anthracis $(\mathrm{MIC}=$ $0.195 \mathrm{mg} / \mathrm{mL})$, S.typhi $(\mathrm{MIC}=0.781 \mathrm{mg} / \mathrm{mL})$, and
C. neoformans (MIC $=0.195 \mathrm{mg} / \mathrm{mL})$. Antimicrobial activities of $C$. mucronata collected from other parts of the world have already been documented $[10,11]$. Although C. mucronata roots are used by the people of Coast region in Tanzania for treatment of fresh wounds, the antimicrobial activity of the extracts from roots was found to be generally lower than that of the extracts from aerial parts (Table 2). Therefore, the use of root extracts for treatment of fresh wound may suggests that, apart from the weak antibacterial properties, C. mucronata root extract might has other properties such as anti-inflammatory property. Furthermore, these results suggest that, the aerial parts of this plant species may substitute roots in the preparation of herbs needed in the treatment of wounds and other bacterial infection.

All ethanolic extracts of $T$. villosa exhibited larvicidal activity, with highest activity being in the fruit extract which had $\mathrm{LC}_{50}$ value of $53.25 \mu \mathrm{g} / \mathrm{mL}$. Furthermore, extracts from leaves and twigs were not toxic to brine shrimp $\left(\mathrm{LC}_{50}>100 \mu \mathrm{g} / \mathrm{mL}\right)$ whereas extracts from fruits and roots were very toxic to brine shrimp with $\mathrm{LC}_{50}<10$ $\mu \mathrm{g} / \mathrm{mL}$ (Table 1). Interestingly, the $\mathrm{LC}_{50}$ value of twigs extract in the larvicidal activity was lower than the $\mathrm{LC}_{50}$ for brine shrimp toxicity. This suggests that, ethanolic extract from twigs may be useful as larvicides in the control of the spread of mosquito-borne diseases. This observation corroborates the earlier reports on the seeds of $T$. vogelii which share the same genus as T. villosa. The seeds of $T$. vogelii are reported to have larvicidal activity against Aedes aegti larvae [25].

Brine shrimp results obtained from fruits and roots support previous claims of $T$. villosa toxicity to animals and fish [14] and medicinal use of leaf extract (16). Fruit and root extracts of $T$. villosa were found to be very toxic with their $\mathrm{LC}_{50}$ values below that of the anticancer 
drug, cyclophosphamide whereas leaf and twig extracts were found to be non-toxic (Table 1). This suggests that the toxic characteristic of $T$. villosa is due to the fruits and roots, and strengthen the speculation for potential to yield anticancer agents (26).

The ethanolic extracts from $T$. villosa were also evaluated for their antimicrobial properties. The extracts with promising antimicrobial activity were from fruits against C.neoformans with MIC $=0.195 \mathrm{mg} / \mathrm{mL}$, roots against B. anthracis with MIC $=0.195 \mathrm{mg} / \mathrm{mL}$ and leaves against E. coli with $\mathrm{MIC}=0.781 \mathrm{mg} / \mathrm{mL}$. When compared with other species in the same genus, most of the species reported earlier showed no or weak antimicrobial properties [26]. Some of the reported antimicrobial activities from the genus Tephrosia are of methanolic extract from aerial parts of $T$. apollinea which was active against C. albicans and of aqueous extract from the entire T. purpurea which was active against $S$. aureus $[27,28]$. Although most of the extracts from $T$. villosa showed weak antibacterial and antifungal activity, the good activity observed from the fruit extract against $C$. neoformans suggests that further studies is needed to identify bioactive compound responsible for the antimicrobial activity.

\section{Conclusion}

These results support the use of C. mucronata in traditional medicine for treatment of wounds. Extracts of C. mucronata have potential to yield active antimicrobial and larvicidal compounds. The high brine shrimp toxicity of T. villosa corroborates with literature reports that the plant is toxic to both livestock and fish. The results further suggest that $T$. villosa extracts have potential to yield larvicidal and possibly cytotoxic compounds. Further studies to investigate the bioactive compounds responsible for the observed biological effects are suggested.

\section{Acknowledgements}

We are grateful to Mr. Shabani Ngesile for collection of the plant materials and Mr. Selemani O. Haji for identification of the plant materials. Authors are also grateful to the NAPRALERT data bank of UIC, and MUHAS for financial support through the fund released to the Department of Biological and PreClinical Studies.

\begin{abstract}
Author details
${ }^{1}$ Department of Biological and Pre-Clinical Studies, Institute of Traditional Medicine, Muhimbili University of Health and Allied Sciences (MUHAS), P.O. Box 65001, Dar es Salaam, Tanzania. ${ }^{2}$ Department of Natural Products Development and Formulation, Institute of Traditional Medicine, MUHAS, P. O.BOX 65001, Dar es Salaam, Tanzania. ${ }^{3}$ Department of Physical Sciences, Open University of Tanzania, P.O. Box 31608, Dar es Salaam, Tanzania.
\end{abstract}

\section{Authors' contributions}

RSON: was responsible for study concept, study design, methodological development, data acquisition and data analysis, and writing the manuscript. ZHM: was responsible for coordinating the research activities and writing the manuscript. AWK: was responsible for study concept, study design, methodological development and data acquisition. EMI: was responsible for methodological development, coordinating the research and revising the manuscript. MJM: was involved in coordinating the study and revising the manuscript. PE: was involved in methodological development and revising the manuscript. MJM: was involved in coordinating the study and revising the manuscript. All authors read and approved the final manuscript.

\section{Competing interests}

The authors declare that they have no competing interests.

Received: 31 December 2010 Accepted: 23 April 2011

Published: 23 April 2011

\section{References}

1. Muthaura CN, Rukunga GM, Chhabra SC, Mungai GM, Njagi ENM: Traditional Antimalarial Phytotherapy Remedies used by the Kwale Community of the Kenyan Coast. J Ethnopharmacol 2007, 114:377-386.

2. PROTA BASE. [http://database.prota.org/publishedspeciesEn.htm].

3. C. pareila and C. mucronata, Menispermaceae. [http://www.mmh-mms. com/downloads/mp08cissampelospareira.pdf].

4. Johns T, Muhoro EB, Sanaya P, Kimanani EK: Herbal Remedies of the Batemi of Ngorongoro District, Tanzania: A Quantitative Appraisal. Econ BOT 1994, 48(1):90-95.

5. Gessler MC, Nkunya MH, Mwasumbi LB, Heinrich M, Tanner M: Screening Tanzanian Medicinal Plants for Antimalarial Activity. Acta Trop 1994, 56(1):65-77.

6. Sparg SG, Van Staden J, Jager AK: Efficiency of Traditionally Used South African Plants against Schistosomiasis. J Ethnopharmacol 2000, 73(1):209-214

7. Selvanayahgam ZE, Gnanevendhan SG, Balakrishna K, Rao RB: Antisnake Venom Botanicals from Ethnomedicine. J Herbs Spices Med Plants 1994, 2(4):45-100.

8. Tshibangu JN, Chifundera K, Kaminsky R, Wright AD, König GM: Screening of African Medicinal Plants for Antimicrobial and Enzyme Inhibitory Activity. J Ethnopharmacol 2002, 80:25-35.

9. Akah PA, Nwafor SV, Okoli CO: Evaluation of the Sedative Properties of the Ethanolic Root Extract of Cissampelos mucronata. Boll Chim Farm 2002, 141(3):243-6

10. Taniguchi IM, Chapya A, Kubo I, Nakanishi K: Screening of East African Plants for Antimicrobial Activity. Chem Pharm Bull 1978, 26:2910-2913.

11. Nwafor SV: Investigation of the Antiulcer Properties of the Methanolic Leaf Fraction of Cissampelos mucronata. AJST, Engineering series 2004, 5(1):109-114.

12. Nwafor SV, Akah PA: Effect of Methanolic Leaf Extract of Cissampelos mucronata A.Rich. Against Indomethacin-induced Ulcer in Rats. Indian J Exp Biol 2003, 41(2):181-183.

13. Tanko Y, Yaro AH, Isa Al, Yerima M, Salehe MIA, Mohamedi A: Toxicological and Hypoglycaemic Studies on the Leaves of Cissampelos mucronata (Menispermaceae) on Blood Glucose Levels of Streptozotocin-induced Diabetic Wistar Rats. J Med Plant Res 2007, 1(5):113-116.

14. Orwa C, Mutua A, Kindt R, Jamnadass R, Simons A: Agroforestree Database: A Reference and Selection Guide Version 4.0. [http://www. worldagroforestry.org/treedb2/AFTPDFS/Tephrosia_villosa.pdf].

15. Kapoor SL, Kapoor LD: Medicinal Plant Wealth of the Karimnagar District of Andhra Pradesh. Bull Med Ethnobot Res 1980, 1:120-144.

16. Jain SR, Sharma SN: Hypoglycaemic Drugs of Indian Indigenous Origin. Planta Medica 1967, 15(4):439-442.

17. WHO Health organization: Protocols for Laboratory and Field Evaluation of Insecticides and Repellents: Report of the WHO Informal Consultation on the Evaluation and testing of Insecticides. Ref: CTD/WHOPES/IC/96.1. Geneva 1996.

18. Ellof JN: A quick Microplate Method to Determine the Minimum Inhibitory Sensisitive and Concentration of Plant Extracts for Bacteria. Planta Medica 1998, 64:711-713.

19. Meyer BN, Ferrign RN, Putnam JE, Jacobson LB, Nicholas DE, McLaughlin JL: Brine Shrimp:A Convenient General Bioassay for Active Plant Constituents. Planta Medica 1982, 45:31-34.

20. Litchfield JR Jr, Wilcoxon F: A Simplified Method of Evaluating Dose-Effect Experiments. J Pharmacol and Exp Therap 1949, 96:99-138.

21. Moshi MJ, Innocent E, Magadula JJ, Otieno DF, Weisheit A, Mbabazi PK, Nondo RSO: Brine Shrimp of Some Plants used as Traditional Medicine 
in Kagera Region, Northw West Tanzania. Tanzania Journal of Health Research 2010, 12(1):63-67.

22. World Health Organization: World Malaria Report. Geneva 2008.

23. Gu HJ, Cheng SS, Huang CG, Chen WJ, Chang ST: Mosquito Larvicidal Activities of Extractives from Black Heartwood-type Cryptomeria japonica. Parasitol Res 2009, 105:1455-1458.

24. Aligiannis N, Kalpotzakis E, Mitaku S, Chinou IB: Composition and Antimicrobial Activity of the Essential oils of Two Origanum species. J Agr Food Chemistry 2001, 40:4168-4170.

25. Monson D: The Action of Certain Assamese Plants as Larvicides. J Malaria Inst india 1939, 2:35.

26. NAPRALERT DATABASE: University of Illnonois. Chicago; 2010

27. Bashir AK, Hassan ESS, Amiri MH, Abdalla AA, Wasfi IA: Antimicrobial Activity of Certain Plants Used in Folk-Medicine of United Arab Emirates. Fitoterapia 1992, 63(4):371-375.

28. Adoum OA, Dabo NT, Fatope MO: Bioactivities of Some Savanna Plants in the Brine Shrimp Lethality test and In Vitro Antimicrobial Assay. Int J Pharmacog 1997, 35(5):334-337.

\section{Pre-publication history}

The pre-publication history for this paper can be accessed here: http://www.biomedcentral.com/1472-6882/11/33/prepub

doi:10.1186/1472-6882-11-33

Cite this article as: $O$ Nondo et al: Larvicidal, antimicrobial and brine shrimp activities of extracts from Cissampelos mucronata and Tephrosia villosa from coast region, Tanzania. BMC Complementary and Alternative Medicine 2011 11:33.

\section{Submit your next manuscript to BioMed Central and take full advantage of:}

- Convenient online submission

- Thorough peer review

- No space constraints or color figure charges

- Immediate publication on acceptance

- Inclusion in PubMed, CAS, Scopus and Google Scholar

- Research which is freely available for redistribution

Submit your manuscript at www.biomedcentral.com/submit 